\title{
Oxidative stress features in patients with combined course of type 2 diabetes mellitus and osteoporosis residing in anthropogenic pressure conditions
}

\author{
V. I. Kryvenko, O. I. Borodavko*
}

Zaporizhzhia State Medical University, Ukraine

Key words: oxidative stress, osteoporosis, type 2 diabetes mellitus.

\section{Zaporozhye} medical journal 2019; 21 (2), 182-186 D0l: 10.14739/2310-1210 2019.2.161364

*E-mail: oleo1714@gmail.com
The purpose of the study is to compare indicators of oxidative stress (OS) and bone mineral density in patients with combined course of type 2 diabetes mellitus (DM) and osteoporosis (OP), who are permanently resident in industrial regions and in environmentally friendly conditions.

Materials and methods. A total of 74 patients with combined course of type $2 \mathrm{DM}$ and OP have been examined. The main group included 50 patients who had permanent residence in Zaporizhzhia city (industrial region). The comparison group included 24 patients with combined course of type $2 \mathrm{DM}$ and OP who were born and lived in Mykhailivka town of the Zaporizhzhia region (ecological region). All the patients underwent ultrasound densitometry using the Omnisense 7000 ultrasound densitometer (Beam Medical Ltd, Israel). Osteoporosis risk index (ORI) was calculated for each patient as an average index for 2 bones. The OS intensity was assessed by nitrotyrosine and 8-hydroxyguanine serum levels. Serum glucose and glycosylated hemoglobin $(\mathrm{HbA} 1 \mathrm{c})$ were also measured.

Results. The main group patients did not significantly differ from the comparison group patients in terms of OP risk factors, age, gender, duration and course of type $2 \mathrm{DM}$. The mean values of nitrotyrosine and 8-hydroxyguanine levels were significantly 2.5 times $(P<0.05)$ and 1.4 times $(P<0.05)$ higher, respectively, in the main group as compared to similar patients from the environmentally friendly region. The bone mineral density in the industrial region group was significantly lower. Thus, the Rad-Tib ORI was $12 \%$ higher in the main group, Rad-Ph ORI - by $19 \%$, and Tib-Ph ORI - by $16 \%$ compared with the comparison group $(P<0.05)$.

Conclusions. The processes of OS are intensified and severity of osteoporosis is increased in the patients with combined course of type 2 diabetes mellitus and OP who have been permanently living in the large industrial city compared to the residents of the environmentally friendly region.
Киючові слова: оксиАативний стрес, остеопороз, цукровий діабет 2 типу.

Запорізький медичний

журнал. - 2019. T. 21, № 2(113), C. 182-186

Особливості оксидативного стресу у хворих із поєднаним перебігом цукрового діабету 2 типу та остеопорозу, які постійно проживають в умовах антропогенного навантаження

\section{В. І. Кривенко, О. І. Бородавко}

Мета роботи - здійснити порівняльний аналіз показників оксидативного стресу (ОС) і мінеральної щільності кісткової тканини у хворих із поєднаним перебігом цукрового діабету (ЦД) 2 типу та остеопорозу (ОП), які постійно проживають у промисловому регіоні та в екологічно сприятливих умовах.

Матеріали та методи. Обстежено 74 пацієнти з поєднаним перебігом ЦД 2 типу та ОП. До основної групи увійшли 50 пацієнтів, які постійно проживали у м. Запоріжжі (промисловий регіон). До групи порівняння увійши 24 пацієнти з поєднаним перебігом ЦД 2 типу та ОП, які народилися й жили у смт Михайлівка Запорізької області (екологічно сприятливий регіон). Усім пацієнтам виконали ультразвукову денситометрію на ультразвуковому денситометрі Omnisense 7000 (Beam Medical Ltd, Israel). Також розраховували індекс ризику остеопорозу (IPO) - середній коефріцієнт для 2 кісток. Оцінювання стану кісткової тканини проводили за критеріями ВОО3. Інтенсивність ОС оцінювали за рівнем нітротирозину та 8-гідроксигуаніну в сироватці крові. Також здійснили дослідження глюкози натще та $\mathrm{HbA1c}$

Результати. Пацієнти основної групи вірогідно не відрізнялись за фракторами ризику ОП, віком, статтю, тривалістю та перебігом ЦД 2 типу від осіб групи порівняння. Середні значення рівня нітротирозину та 8-гідроксигуаніну були вірогідно вищими в основній групі у 2,5 раза $(p<0,05)$ та 1,4 раза $(p<0,05)$ відповідно порівняно з аналогічними хворими з екологічно сприятливого регіону. Мінеральна щільність кісткової тканини у групі з промислового регіону була вірогідно нижчою. Так, IPO Rad-Tib був на 17 \% вищим в основній групі, IPO Rad-Ph - на 16 \%, a IPO Tib-Ph - на 27 \% щодо групи порівняння.

Висновки. У хворих із поєднаним перебігом ЦД 2 типу та ОП, які постійно проживали в умовах великого індустріального міста, визначили інтенсифікацію процесів ОС і підвищення виразності ОП порівняно з мешканцями екологічно сприятливого регіону.

Ключевые слова: оксиАативный стресс, остеопороз, сахарный Аиабет 2 типа.

Запорожский медицинский журнал. - 2019. -

T. 21, № 2(113). C. 182-186

\section{Особенности оксидативного стресса у больных с сочетанным течением сахарного} диабета 2 типа и остеопороза, которые постоянно проживают в условиях антропогенной нагрузки

\section{В. И. Кривенко, О. И. Бородавко}

Цель работы - провести сравнительный анализ показателей оксидативного стресса (OC) и минеральной плотности костной ткани (МПКТ) у больных с сочетанным течением сахарного диабета (СД) 2 типа и остеопороза (ОП), которые постоянно проживают в промышленном регионе и в экологически благоприятных условиях. 
Материалы и методы. Обследовали 74 больных с сочетанным течением СД 2 типа и ОП. В основную группу вошли 50 пациентов, которые постоянно проживали в г. Запорожье (промышленный регион). В группу сравнения включены 24 пациента с сочетанным течением СД 2 типа и ОП, которые родились и жили в пгт Михайловка Запорожской области (экологически благоприятный регион). Всем пациентам проводилась ультразвуковая денситометрия на ультразвуковом денситометре Omnisense 7000 (Beam Medical Ltd, Israel). Также рассчитывали индекс риска остеопороза (ИРО) - средний коэффициент для 2 костей. Оценка состояния костной ткани проводилась по критериям ВОЗ. Интенсивность ОС оценивали по уровню нитротирозина и 8-гидроксигуанина в сыворотке крови. Также проводили исследования глюкозы натощак и $\mathrm{HbA1c.}$

Результаты. Пациенты основной группы достоверно не отличались по факторам риска ОП, возрасту, полу, длительности и течению СД 2 типа от лиц группы сравнения. Средние значения уровня нитротирозина и 8-гидроксигуанина были достоверно выше в основной группе в 2,5 раза $(p<0,05)$ и 1,4 раза $(p<0,05)$ соответственно по сравнению аналогичными больными из экологически благоприятного региона. Минеральная плотность костной ткани в группе из промышленного региона была достоверно ниже. Так, ИРО Rad-Тib был на 17 \% выше в основной группе, ИРО Rad-Ph - на 16 \%, а ИРО Tib-Ph - на 27 \% относительно группы сравнения.

Выводы. У больных с сочетанным течением СД 2 типа и ОП, которые постоянно проживали в условиях крупного индустриального города, имеет место интенсификация процессов ОС и повышение выраженности ОП по сравнению с жителями экологически благоприятного региона.

\section{Introduction}

People living in conditions of technogenic civilization are subjected to development of pathologic changes in organs and systems. The negative influence of environmental factors (air pollution by emissions from transport and industrial enterprises, xenobiotics, ultraviolet radiation, etc.) is accompanied by the increased formation of free radicals [1]. According to the literature, oxidative stress (OS) caused by adverse environmental conditions is one of the determining factors in the pathogenesis of a range of diseases, including diabetes mellitus (DM) and osteoporosis (OP) $[1,2]$.

Harmful substances can affect bone tissue, both directly and indirectly. Therefore, cadmium, in particular, inhibits the formation of a hormonally active form of vitamin D3 (calcitriol) in proximal renal tubules, which leads to a decrease in the calcium absorption from the digestive tract $[3,4]$. Lead is accumulated in bone tissue, replacing calcium and thereby decreasing bone mineral density (BMD) [5].

Indirect impact is caused by OS development. As a result of environmental contamination, active oxygen forms are accumulated in large quantities in the body, which stimulates the processes of protein and lipid peroxidation and contributes to a reduction in antioxidant defense system activity [1].

In the available literature, we have not found any reports on the OS study in patients with combined course of type $2 \mathrm{DM}$ and OP with regard to the impact of anthropogenic stress, which requires further research.

\section{The purpose}

The purpose of the study is to compare indicators of oxidative stress (OS) and bone mineral density in patients with combined course of type 2 diabetes mellitus (DM) and osteoporosis (OP), who are permanently resident in industrial regions and in environmentally friendly conditions.

\section{Materials and methods}

We have examined 74 patients with the combined course of type $2 \mathrm{DM}$ and OP. The main group included 50 patients who lived permanently in the city of Zaporizhzhia (industrial region).
According to the data collected in the Institute of Medical and Environmental Problems of Zaporizhzhia State Medical University, the content of industrial pollutants in the environment exceeds the maximum permissible concentrations, in particular, heavy metal compounds (lead, copper, manganese, etc.) - 4.7 times, benzo[a] pyrene -6.4 times, ammonia - 1.6 times, phenol -1.3 times, fluorides -2 times, sulfur dioxide -2.5 times, hydrogen sulfide -1.5 times [6].

The comparison group included 24 patients with combined course of type $2 \mathrm{DM}$ and OP who were born and lived in Mykhailivka town of the Zaporizhzhia region.

According to the Main Department of Statistics in the Zaporizhzhia region, this urban-type settlement is located in the region with a relatively favorable ecological situation. For example, in 2014, $52 \mathrm{~kg}$ of harmful substances were emitted per one resident of the Mykhailivka district per year, while this rate was $163 \mathrm{~kg}$ per inhabitant in Zaporizhzhia per year. In addition, the main specific pollutants content, according to the official statistics, is much lower in the atmospheric air of the Mikhailivsky district than in Zaporizhzhia city [6]

The following inclusion criteria were applied: a written informed consent obtained from each patient to participate in the study, verified diagnosis of type 2 DM (according to the Health Ministry of Ukraine Order No. 1118 dated 21.12.2012), verified diagnosis of osteoporosis (according to the Health Ministry of Ukraine Order No. 676 dated 12 October, 2006, and the recommendations of the International Society for Clinical Densitometry, 2015), age from 50 to 70 years old.

Exclusion criteria included diagnosis of type 1 diabetes, secondary insulin-dependent DM, glucocorticosteroids intake for more than 3 months, thyroid disorders, chronic heart failure, chronic kidney disease, systemic connective tissue diseases, women with premature (up to 45 years of age) or artificial menopause.

All the patients underwent ultrasound densitometry of the three bones, namely, proximal phalanx of the III finger, the distal radius, the midshaft tibia using the Omnisense 7000 ultrasound densitometer (Beam Medical Ltd, Israel).

The bone tissue assessment was performed according to the WHO criteria: normal condition - T-index> $-1.0 \mathrm{SD}$, osteopenia - T-index - from -1.0 to -2.5 SD, osteoporosis T-index $<-2.5$ SD [7]. 
Table 1. Characteristics of the examined patients with combined course of type 2 DM and OP depending on the region of residence

\begin{tabular}{l|l|l|l}
\hline Patients characteristics & $\begin{array}{l}\text { Main group } \\
\mathbf{n}=\mathbf{5 0}\end{array}$ & $\begin{array}{l}\text { Comparison group } \\
\mathbf{n}=\mathbf{2 4}\end{array}$ & $\mathbf{P}$ \\
\hline Age, years & $61.0(56.0 ; 65.0)$ & $62(57.5 ; 64.0)$ & 0.71 \\
\hline Gender (m/f) & $20 / 31$ & $10 / 14$ & 0.89 \\
\hline DM duration, years & $5.0(2.0 ; 8.0)$ & $4.0(2.0 ; 6.5)$ & 0.38 \\
\hline Glucose, mmol/I & $10.9 \pm 2.4$ & $10.1 \pm 1.9$ & 0.39 \\
\hline HbA1c, \% & $8.7(7.9 ; 10.6)$ & $8.4(7.6 ; 10.1)$ & 0.45 \\
\hline $\begin{array}{l}\text { Reduced sensitivity in the lower limbs } \\
\text { (yes/no), \% }\end{array}$ & $58 / 42$ & $11 / 13$ & 0.32 \\
\hline $\begin{array}{l}\text { Pain in the lower limbs (yes/no), \% } \\
\text { Heredity for OP (yes/no), \% }\end{array}$ & $22 / 78$ & $16 / 84$ & 0.90 \\
\hline Back pain (yes/no), \% & $12 / 88$ & $8 / 92$ & 0.95 \\
\hline $\begin{array}{l}\text { Fractures with minimal trauma, (yes/no), \% } \\
\text { Height loss 3 cm or more (yes/no), \% }\end{array}$ & $44 / 56$ & $54 / 46$ & 0.13 \\
\hline $\begin{array}{l}\text { Daily alcohol intake more than 2 doses, } \\
\text { (yes/no), \% }\end{array}$ & $10 / 90$ & $25 / 75$ & 0.81 \\
\hline $\begin{array}{l}\text { Smoking (yes/no), \% } \\
\text { Daily physical activity less than 30 minutes }\end{array}$ & $16 / 84$ & $2 / 22$ & 0.80 \\
\hline $\begin{array}{l}\text { (yes/no), \% } \\
\text { Food intolerance (yes/no), \% }\end{array}$ & $16 / 84$ & $8 / 92$ & 0.70 \\
\hline
\end{tabular}

Table 2. The levels of nitrotyrosine and 8-hydroxyguanine in patients with type 2 diabetes and osteoporosis, depending on the region of residence

\begin{tabular}{l|l|l|l} 
Indicator & $\begin{array}{l}\text { Main group } \\
\mathrm{n}=50\end{array}$ & $\begin{array}{l}\text { Comparison group } \\
\mathrm{n}=24\end{array}$ & $\mathbf{P}$ \\
\hline Nitrotyrosine, $\mathrm{nmol} / \mathrm{ml}$ & $41.4(11.7 ; 56.5)$ & $16.6(10.0 ; 32.8)$ & 0.006 \\
\hline 8-hydroxyguanine, $\mathrm{nmol} / \mathrm{ml}$ & $13.0(9.9 ; 15.4)$ & $9.0(7.3 ; 11.5)$ & 0.008 \\
\hline
\end{tabular}

Table 3. Ultrasonic densitometry indicators in patients with a combined course of type $2 \mathrm{DM}$ and OP depending on the region of residence

\begin{tabular}{l|l|l|l|}
\hline Indicators & $\begin{array}{l}\text { Main group } \\
\mathbf{n = 5 0}\end{array}$ & $\begin{array}{l}\text { Comparison group } \\
\mathbf{n = 2 4}\end{array}$ & $\mathbf{P}$ \\
\hline T-index for the radius & $-2.7 \pm 0.9$ & $-2.5 \pm 1.3$ & 0.76 \\
\hline T-index for the tibia & $-2.4 \pm 0.9$ & $-2.1 \pm 1.2$ & 0.30 \\
\hline T-index for the phalanx & $-1.4 \pm 1.1$ & $-1.2 \pm 0.9$ & 0.36 \\
\hline Rad-Tib ORI & $-2.5 \pm 0.6$ & $-2.2 \pm 0.1$ & 0.04 \\
\hline Rad-Ph ORI & $-2.1 \pm 0.4$ & $-1.7 \pm 0.5$ & 0.03 \\
\hline Tib-Ph ORI & $-1.9 \pm 0.7$ & $-16 \pm 0.8$ & 0.04 \\
\hline
\end{tabular}

Osteoporosis risk index (ORI) was calculated for each patient as an average index for 2 bones. When conducting ultrasound densitometry of the three bones, the following combinations were possible: radius bone - tibia (Rad-Tib), radius bone - phalanx (Rad-Ph), tibia- phalanx (Tib-Ph).

The result was presented in the form of T-index, the normative values were the same as in evaluation of ultrasound densitometry indicators according to the WHO criteria.

The OS intensity was assessed by nitrotyrosine (a kit from Hycult Biotech, the Netherlands) and 8-hydroxyguanine (a kit from Enzo Life Sciences, Switzerland) serum levels which were tested by Immunochem-2100 (High Technology, USA) using the immunoassay method.

Nitrotyrosine is a specific marker of oxidative damage to plasma proteins and indicates the pathological activity of peroxynitrite which is one of the most potent oxidants causing protein nitrosation, mitochondrial dysfunction and apoptosis [8].

8-hydroxyguanine is a product of deoxyguanosine hydroxyl radical non-enzymatic oxidation, one of the four
DNA nucleotides, and is the most sensitive marker of nucleic acid damage [9].

Serum glucose and glycosylated hemoglobin $(\mathrm{HbA} 1 \mathrm{c})$ were measured on a Prestige 24i biochemical analyzer (Tokyo Boeki, Japan).

The principles of bioethics have been taken into account in the research: the general principles of the Council of Europe Convention on Human Rights and Biomedicine (04.04.1997), the GCP (1996), the ethical principles of medical research involving human subjects of the World Medical Association Declaration of Helsinki (1964-2000) and the Health Ministry of Ukraine Order No 281 dated 01.11.2000.

Statistical processing was carried out using the Statistica 13.0 for Windows (StatSoft Inc., No JPZ8041382130ARCN10-J) computer program. The adequacy of the parameters to normal distribution was tested using the Shapiro-Wilk test. Descriptive statistics parameters for continuous variables were presented as the arithmetic mean and standard deviation. Results which did not follow normal distribution were expressed as median and interquartile range.

In comparison of studied groups, Student's t-test and Mann-Whitney test were used depending on the symptom distribution. The comparison of qualitative indicators was carried out according to the $\chi^{2}$ criterion.

The Pearson or Spearman correlation coefficients were preferred according to the distribution of variables to assess the nature and strength of the associations between the studied parameters. A P value $<0.05$ was considered statistically significant.

\section{Results}

Table 1 shows the characteristics of the examined patients. The main group patients did not significantly differ from the comparison group patients in terms of the OP risk factors such as age, gender, duration and course of type $2 \mathrm{DM}$.

The mean values of nitrotyrosine and 8-hydroxyguanine levels were significantly 2.5 times $(P<0.05)$ and 1.4 times $(P<0.05)$ higher, respectively, in the main group as compared to similar patients from the environmentally friendly region (Table 2).

According to the literature data, OS can affect bone tissue [10]. That is why, further on, we compared the groups of patients by the results of ultrasonic densitometry (Table 3). The groups did not differ significantly in the T-index for the tibia, radius and phalanx. However, when comparing the groups by ORI, which is a generalized indicator of ultrasound densitometry and indicates the severity of OP, BMD was significantly lower in the industrial region group. Thus, the Rad-Tib ORI was $12 \%$ higher in the main group, Rad-Ph ORI - by $19 \%$, and Tib-Ph ORI - by $16 \%$ compared with the comparison group $(P<0.05)$.

It was specified by the correlation analysis that the increase in nitrotyrosine level was significantly associated with a decrease in T-index for the tibia, radius and Rad-Tib ORI $(r=-0.42, P<0.05 ; r=-0.37, P=0.05 ; r=-0.34, P<0.05)$. An increase in 8-hydroxyguanine level had a significant negative correlation with the T-index for the tibia, Rad-Tib ORI and Tib-Ph ORI $(r=-0.38, P<0.05 ; r=-0.41, P<0.05$; $r=-0.35, P<0.05)$. 


\section{Discussion}

The groups of examined patients were comparable, which is important to exclude the factors that may affect the OS markers. In individuals who have been living in the industrial region, the levels of nitrotyrosine and 8-hydroxyguanine were significantly higher compared to the similar patients from the environmentally friendly region. These data indicate the OS intensification and point to a high oxidative modification of proteins and DNA in patients with combined course of type $2 \mathrm{DM}$ and OP who have been constantly exposed to anthropogenic pressure (Table 2).

It should be noted that endogenous production of active oxygen forms occurs during normal physiological processes and such factors as industrial pollutants, ultraviolet radiation or air pollution contribute to their formation and accumulation [11]. It is believed, hat the body of an individual who resides in an industrial region can be affected by several hundred thousand of chemicals, combined effect of which can lead to an increase in their toxicity, despite their small amounts [12]. According to scientists, the workers exposed to carbon dioxide demonstrated an increase in malonic aldehyde level and a decrease in antioxidant system markers - superoxide dismutase, catalase and peroxidase, which indicates the OS development [13].

The literature data show that active oxygen forms can affect bone tissue [10]. In our study, the groups did not differ significantly by T-indexes for phalanx, tibia and radius bones, but a significant difference was found by ORI, which is a generalized indicator of ultrasound densitometry and indicates the severity of OP, which may be explained by higher $O S$ rates. The obtained data are confirmed by the presence of a possible reverse correlation of the OS markers levels with ORI and T-index.

There are limited literature data that city residents have a higher incidence of OP and osteopenia compared to rural residents. So, according to V. V. Povorozniuk, V. M. Vajda, N. I. Dzerovych (2010), a significantly higher incidence of fractures was registered among urban compared to rural residents [14].

The results of the experimental studies testify the development of structural changes in bone tissue, as well as an imbalance in the bone turnover under the influence of combined effects of toxicants [4]. Industrial pollutants promote activation of free radical processes in case of antioxidant deficiency, which adversely affects the BMD, bone turnover causing the development of OP. It was revealed that the workers who have harmful working conditions exhibit changes in the bone turnover and OP development more often and at younger ages [15].

The results obtained indicate that the OS processes are intensified in patients with a combined course of type 2 diabetes and OP who have been permanently living in the large industrial city compared with the residents of the environmentally friendly region. It is logical to assume that in the conditions of chronic oxidative stress, there is a dysregulation of adaptive processes and a decrease in the reserve capacity of adaptive responses. It is advised that the patients with combined course of type $2 \mathrm{DM}$ and OP permanently residing under anthropogenic pressure should use pharmacological agents with antioxidant properties in the complex treatment to reduce the effect OS.

\section{Conclusions}

1. There is an increase in nitrotyrosine and 8-hydroxyguanine levels in patients with combined course of type 2 $\mathrm{DM}$ and $\mathrm{OP}$ who permanently reside in the industrial region, which indicates the development of OS in this category of patients.

2. Individuals who permanently reside under the anthropogenic stress have an increase in the severity of osteoporosis according to ORI, compared to the similar patients from the ecological region.

Prospects for further research. To estimate the effectiveness of antioxidant therapy in patients with combined course of type $2 \mathrm{DM}$ and OP who permanently reside in the industrial region.

\section{Funding}

The study was carried out within the framework of the research work Zaporizhzhia State Medical University: "Diagnosis, treatment and prophylaxis of comorbid pathology of internal organs in the conditions of the industrial region" (state registration number 0115U001765).

Conflicts of interest: authors have no conflict of interest to declare. Конфлікт інтересів: віАсутній.

Надійшка Ао редакції / Received: 07.11.2018

Після Аоопрацювання / Revised: 04.12.2018

Прийнято Ао Аруку / Accepted: 13.12.2018

Information about authors:

Kryvenko V. I., MD, PhD, DSc, Professor, Head of the Department of Family Medicine, Therapy, Cardiology and Neurology, Faculty of Postgraduate Education, Zaporizhzhia State Medical University, Ukraine.

Borodavko O. I., MD, Postgraduate Student of the Department of Family Medicine, Therapy, Cardiology and Neurology, Faculty of Postgraduate Education, Zaporizhzhia State Medical University, Ukraine.

Відомості про авторів:

Кривенко В. І., А-р меА. наук, професор, зав. каф. сімейної медицини, терапії, кардіології і неврології ФПО, Запорізький Аержавний медичний університет, Україна.

Бородавко О. І., аспірант каф. сімейної меАицини, терапії, кардіології і неврології ФПО, Запорізький Аержавний меАичний університет, Україна.

\section{Сведения об авторах:}

Кривенко В. И., А-р меА. наук, профессор, зав. каф. семейной меАицины, терапии, карАиологии и неврологии ФПО,

Запорожский государственный медицинский университет, Украина.

Бородавко О. И., аспирант каф. семейной медицины, терапии, кардиологии и неврологии ФПО, Запорожский государственный медицинский университет, Украина.

References

[1] Nagornaya, N. V., \& Chetveryk, N. A. (2010). Oksidativnyj stress: vliyaniye na organizm cheloveka, metody ocenki [Oxidative Stress: Its Influence on a Human Body, Estimation Methods]. Zdorov'ye rebenka, 2(23), 140-145. [in Russian]

[2] Sendur, O. F., Turan, Y., Tastaban, E., \& Serter, M. (2009). Antioxidant status in patients with osteoporosis: a controlled study. Joint Bone Spine, 76(5), 514-8. doi: 10.1016/j.jbspin.2009.02.005

[3] Antonyak, H. L., Babych, N. O., Biletska, L. P., Panas, N. E., \& Zhylishchych, Y. V. (2010). Kadmii v orhanizmi liudyny i tvaryn. Vplyv na funktsionalnu aktyvnist orhaniv i system [Cadmium in human and animal 
organism. II. Effect on functional activity of organs and systems]. Biolohichni studii, Studia Biologica, 4(3), 125-136. [in Ukrainian]. doi: https:// doi.org/10.30970/sbi.0403.110

[4] Khopta, N. S. (2015). Vplyv solei kadmiiu ta nitrytiv na metabolizm u kistkovii tkanyni (Avtoref. dis...kand. biol. nauk). [Influence of cadmium and nitrite salts on bone tissue metabolism]. (Extended abstract of candidate's thesis). Lviv. [in Ukrainian].

[5] Biletska, E. M., Onul, N. M., \& Kalinicheva, V. V. (2016). Porivnialna otsinka bioprotektornoi dii tsynku v orhanichnii ta neorhanichnii formi na osteotropnist svyntsiu v eksperymentalnykh umovakh [Comparative evaluation of bioprotective action of zinc in organic and inorganic form on osteotropism of lead in experimental conditions]. Medychni perspektyvy, 21(4), 123-129. [in Ukrainian].

[6] Holoveshka, V. P. (2015). Statystychnyi shchorichnyk Zaporizkoi oblasti za 2014 rik [Statistical Yearbook of Zaporizhzhia region for 2014]. Zaporizhzhia: Holovne upravlinnia statystyky u Zaporizkii oblasti. [in Ukrainian].

[7] (2015) Official Positions of The International Society for Clinical Densitometry - 2015. Retrieved from https://iscd.app.box.com/v/ OP-ISCD-2015-Adult

[8] Makurina, G. I. (2015). Nitroziruyushchij stress pri psoriaticheskoj bolezni v sochetanii s e'ssentsial'noj gipertenziej [Nitrosative Stress in Psoriatic Diseases Combined with Essential Hypertension]. Vestnik problem biologii i mediciny, 2, 3(123), 159-165. [in Russian].

[9] Pesta, D., \& Roden, M. (2017). The Janus Head of Oxidative Stress in Metabolic Diseases and During Physical Exercise. Curr Diab Rep., 17(6), 41. doi: 10.1007/s11892-017-0867-2

[10] Sorokin, B. V., \& Kostenko, V. A. (2013). Kharakter remodelirovaniya kostej pri vosproizvedenii e'ksperimental'nogo osteoporoza pri khronicheskoj intoksikacii nitrata natriya [Pattern of bone remodeling under experimental osteoporosis and chronic sodium nitrate intoxication]. Zhurnal Grodnenskogo gosudarstvennogo medicinskogo universiteta, 4(44), 074-077. [in Russian].

[11] Da Costa, L. A., García-Bailo, B., Badawi, A., \& El-Sohemy, A. (2012). Genetic determinants of dietary antioxidant status. Mol. Biol. Transl. Sci., 108, 179-200. doi: 10.1016/B978-0-12-398397-8.00008-3

[12] Pastushkova, E. V. (2016). Analiz svyazi vozniknoveniya oksidativnogo stressa s e'kologicheskoj obstanovkoj na primere Sverdlovskoj oblasti [Analysis of the association of the occurrence of oxidative stress ecological conditions on the example of Sverdlovsk region]. Nauchnoe obozrenie. Biologicheskie nauki, 6, 53-59. [in Russian].

[13] Luo, J. C., Shih, T. S., Chang, C. P., \& Huang, C. C. (2011). Blood oxidative stress in taiwan workers exposed to carbon disulfide. American Journal of Industrial Medicine, 54(8), 637-45. doi: 10.1002/ajim.20971

[14] Povorozniuk, V. V., Vajda, V. M., \& Dzerovych, N. I. (2010). Vikovi ta statevi osoblyvosti chastoty perelomiv stehnovoi kistky u naselennia Zakarpatskoi oblasti. [Age and gender features of the frequency of femoral fractures in the population of the Zakarpattia region]. Problemy stareniya i dolgoletiya, 1, 99-106. [in Ukrainian].

[15] Bikmetova, E'. R., Ramazanova, L. M., Men'shikova, I. A., \& Kulagina, I. G. (2010). Osobennosti obmena kostnoj tkani u rabotnikov khimicheskogo predpriyatiya, imeyushchikh proizvodstvennyj kontakt s khlorproizvodnymi nizkomolekulyarnykh alifaticheskikh uglevodorodov [Features of bone tissue exchange in workers of a chemical enterprise who have industrial contact with chlorine derivatives of low molecular weight aliphatic hydrocarbons]. Klinicheskaya biokhimiya: edinstvo fundamental'noj nauki i laboratornoj diagnostiki. Proceedings of the Regional Scientific and Practical Conference (P. 20-24). Izhevsk. [in Russian]. 